\title{
Sustainability of Buildings in Historic City of Malacca
}

\author{
Wan Hashimah Wan Ismail \\ Faculty of Built Environment, \\ Universiti Teknologi Malaysia, Malaysia \\ wan7137shima@gmail.com
}

\begin{abstract}
The paper discusses the sustainability of the buildings on the western side of the Historic City of Malacca with the help of the implementation of conservation policies. It covers the historical background, the role of the local government and the responses of the local residents. The methodology includes site observation, building study, literature review and interview. The findings of the research suggest that the buildings within the areaare well sustained but some local residents gave negative responses. Some strategies are needed to ensure the continuous use and sustainability of the buildings.

Keywords: sustainable, resident, historic building

eISSN 2514-751X @ 2018. The Authors. Published for AMER ABRA CE-Bs by e-International Publishing House, Ltd., UK. This is an open access article under the CC BY-NC-ND license (http://creativecommons.org/licenses/bync-nd/4.0/). Peer-review under responsibility of AMER (Association of Malaysian Environment-Behaviour Researchers), ABRA (Association of Behavioural Researchers on Asians) and CE-Bs (Centre for EnvironmentBehaviour Studies), Faculty of Architecture, Planning \& Surveying, Universiti Teknologi MARA, Malaysia.

DOI: https://doi.org/10.21834/aje-bs.v3i7.269
\end{abstract}




\subsection{Introduction}

Malaysia has many settlements of historic and cultural significance that are worthy of preservation for sustainable development. However, many of them are subjected to urban modernisation. In some settlements uncontrolled developments have resulted in the building of new buildings or facades sandwiched in between old buildings. Currently only two historic cities namely Malacca and Penang are inscribed as UNESCO World Heritage Sites in Malaysia. In both cities the historic buildings are still intact and will remain so only with proper management.

The paper discusses the implementation of policies, how it helped to ensure the sustainability of the buildings in the Historic City of Malacca and the responses of the local residents. It is focused on the western side of Malacca River. The paper is elaborated in three sections. The first section concerns the historical background on the transformation of the area from a rural into a well known commercial area. This includes the changes in ownership and function of the buildings in the area over the years. The transformation is evident in the façade treatments and in some cases in the height of the building. Several buildings within the area are studied as examples of the transformation. The second section elaborates on the role of the local government in the survival of the buildings. Both the steady structure of the old buildings and the policies imposed by the local governmentparticularly on the firstblock had helped to retain the buildings. This happened despite the difficulties in fully implementing the policies and the on going developments in close vicinity to the area. The third section discusses the local residents' responses to the conservation policies and the suitability of the old structures to the current requirements.

\subsection{Literature Review}

Conservation has been regarded as a tool to safeguard the historic buildings. Historic buildings differ from most other cultural properties in that they generally have to be used, able to withstand dead and live loadings as well as able to resist all the causes of decay. Thus, conservation of historic buildings includes maintenance and may according to circumstances include preservation, restoration, reconstruction and adaptation or a combination of these approaches.

It was emphasised that some of the reasons that lead to the destruction of historic buildings are natural decay, neglect by owners and occupiers, new developments, lack of awareness by the public, and inadequate maintenance (Nor Zalina, 2007). To ensure the sustainability of the historic buildings they need somehow to be adapted to the new needs of the inheritors. The practice of adapting buildings for new uses is not something new and had started even in the Middle Ages as emphasised by scholars such as Fielden (1982) and Jokilehto (2002). Classic examples include the rehabilitation of Roman Baths of Diocletian that were converted to a church, museum, cinema and planetarium. The other example is the King's Manor at York. The building was used as the lodging, then consequently as king's palace, administrative centre, tenements, workshop for the blind persons and a university building (Fielden, 1982). These examples also show that the historic buildings survive due to their usefulness to the respective different users over the years. 
Local examples in this aspect are the Central Market in Kuala Lumpur and Cheong Fatt Tze in Penang. The Central Market was built as a wet market in 1888. There were plans to demolish the site in 1970s but was halted with the intervention of the Malaysian Heritage Society that declared it as a 'Heritage Site'. The market was renovated in 1985 and currently a big cultural landmark in Kuala Lumpur with souvenir shops and eateries. Cheong Fatt Tze is another example of a historic building saved from demolition. It was built in 1880 as a mansion cum office and was converted into a boutique hotel in 1990s.

In adapting an old building to a new use, it was emphasised by scholars that its original character must be preserved as much as possible (Cantacuzino and Brandt, 1980; Jokilehto, 2002; Zalina, 2009). Therefore, each building need to be studied before recommendation can be made on their new uses in the context of the needs of the community. This is to ensure the preservation of values in the historic building.

Conservation policies are thus laid in one way or the other to ensure that the heritage buildings are handled to retain its originality. Thus, the enforcement of conservation policies is another aspect that can help to ensure the survival of the historic buildings. However, the management of the compliance of the policies is not an easy task. This is particularly difficult if the historic buildings are public properties.

\section{History}

The subject of sustainability is checked with the historic buildings on the western side of Malacca River. This area is within the Historic City of Malaccathatwas inscribedasaUNESCO World Heritage Site in July 2008. It forms part of the area defined by Historic Malacca City Council as the 'Main Conservation Zone (Core Zone)'. It is an established fact that Malacca originated from the Malacca Sultanate in the $15^{\text {th }}$ century, and went through the colonisation of the Portuguese (1511-1641) and the Dutch (1641-1824) before coming under the British (18241957) as noted by Laurens, (1998), Lam (2002) and Lim and Fernando (2006).

During the Sultanate period Malacca evolved into an urban, trade- oriented society (Lim and Fernando, 2006). However, there is no evidence of built structures of the era survived perhaps due to the use of semi permanent materials. Since the development of the area was through trading, presumably trading took place on both sides of the Malacca River.

Based on maps and texts of Eredia, the development of Malacca was more on the eastern side of the river where buildings, streets and squares were built according to Portugal's urban traditions. The map below (Figure 1) shows that the western side of the river was marked as suburb, Java bazaar, a church and villages (kampong) of several ethnic groups. The villages include Campon Chelin (or Kampong Kling) occupied by the Indians who had close ties to the Portuguese (Lim and Fernando, 2006).

During the Dutch occupation the wealthier Dutch settlers took over the area west of Malacca River and erected their brick houses in the area noted as Kampong Kling (Lim and Fernando, 2006). This was actually the best part of the colonial town with a good view of the sea. Today this is no longer the case due to the reclamation of land at the back of the row of houses at Tun Tan Cheng Lock Street (known earlier as Heeren Street). 
The plan (Figure 2) shows the formation of the area with streets set out in a rectilinear pattern without a uniform grid. The early street pattern of the settlement known as Kampong Belanda (Dutch Village) was reinforced by the building of row houses which were long and narrow. The development shows very clearly the urban conditions which started to emerge in Malacca when more permanent materials such as brick and clay roof tiles replaced the earlier timber and thatch structures. These buildings also demonstrated the comprehensivebuilding and planning regulations imposed during Dutch rule, which dictated the form and materials permitted for construction. The buildings were built with long typical plan as a result of taxes based on the width of street frontage of each building as imposed by the Dutch administrators (Lim and Fernando, 2006).

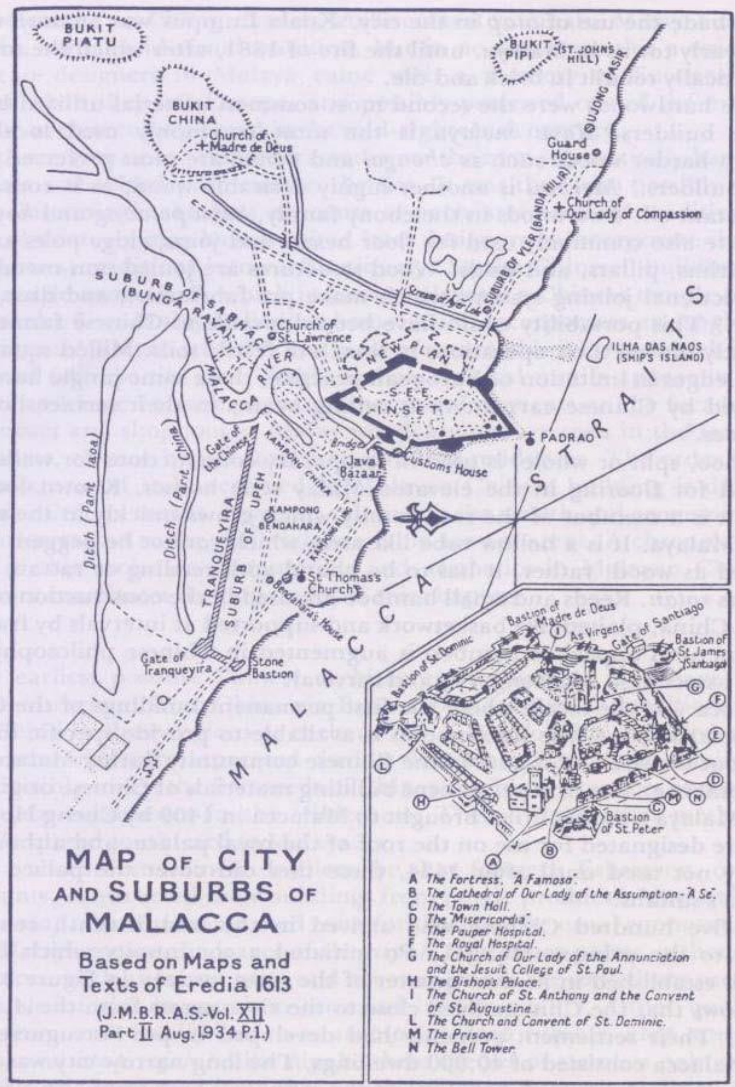

Figure 3.1 - Malacca and suburbs as it existed under the Portuguese in 1613. The foreign merchants' suburb was known as "Tranqueyira", now called Upeh. The Chinese lived in the section of this area closest to the river, designated as Kampung China. ${ }^{12}$

Figure 1: Malacca under the Portuguese Source Kohl (1984) 


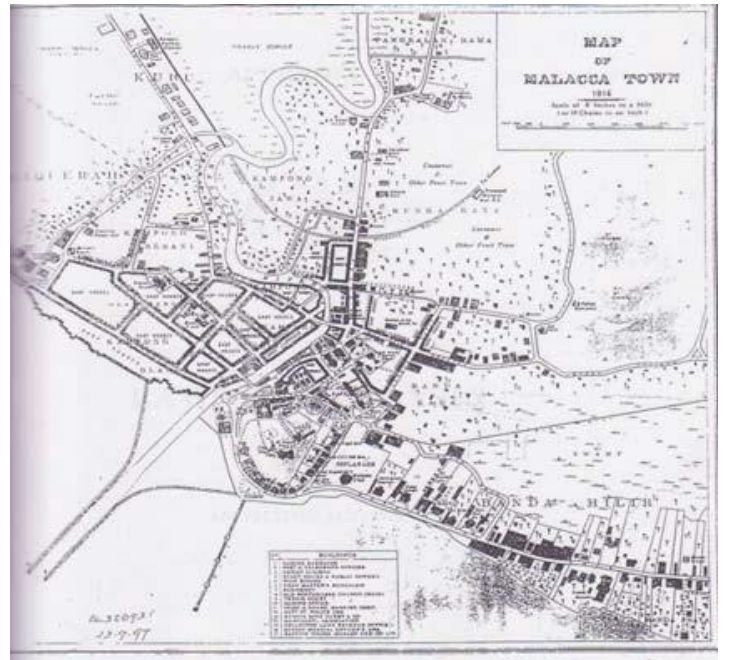

Figure 2: Map of Malacca 1916

Source: Jabatan Muzium dan Antikuiti, 1998

It was during the British occupation of Malacca $(1795-1818,1824-1957)$ in the $19^{\text {th }}$ and $20^{\text {th }}$ century, with the departure of Dutch merchants and families that the rich Chinese started to dominate the area. The displacement of the Dutch by the ethnic Chinese shows that Malacca in the nineteenth century underwent a drastic change and became a town dominated by Asian migrants (Nordin, 2002; Lim and Fernando, 2006).

Modifications were carried out to accommodate the social and cultural traditions of the new owners. From plain Dutch facades, these row houses emerged to have a distinct architectural form characterised by an eclectic combination of western Classical, Chinese and Malay elements. Some of the row houses were also transformed to shop houses that integral to the evolution of the city's streetscapes.

\section{Policies}

The buildings in the historic city of Malacca are subjected to the policies of the State Authority. The State Authority is responsible for the general policy in respect of the planning of the development and use of the lands as well as buildings within the area of every local authority in the state. The guidelines or policies used by the State Authority include the Town and Country Planning Act, 2001 (Act 172), Malacca Enactment no.6 of 1988, Control of Rent (repeal) Act 1997 (Act 572) and the National Heritage Act (2005). According to Controller 3 the policies used for old buildings in Malacca in the past were Town and Country Planning Act, 1976 (Act 267) and Malacca Enactment no.6 of 1988.

The Malacca Enactment no.6 of 1988 allows the local government to obtain its revenue from taxes, rates, fees and fines from the rate payers within its area. In addition it also 
receives grants and contributions both from the federal and state governments. The Enactment also placed Historic Malacca City Council (MBMB) to be in-charge of the conservation of old buildings. It is noted, "Any cultural heritage which has been declared to be preserved or conserved shall be inspected at all reasonable times by an officer authorized by the Local Authority." The Enactment ensured that no new building is built within the historic town and no old building tobe demolished. The height of the new building had to be no higher than the existing lower adjacentbuilding. The interior after the firstblock, however, is left to the discretion of the owner (Controller 2).

The Town and Country Planning Act 1976 (Act 172) ensure proper control and regulation of town and country planning in local authority areas. It details the planning powers of the local government and enables it to be a development agent authorized with the role of a catalyst for development of the area under its jurisdiction. The Act was upgraded and is now known as the Town and Country Planning Act, 2001 (Act 172).

The Control of Rent Act 1966 (as on $1^{\text {st }}$ August 1985) prevented the eviction of tenants of all pre-war rented properties without compensation as well as for purposes of demolishing for development. The act also ensures this building type to be in its original condition. However, it was later reviewed and the outcome was the Control of Rent (repeal) Act 1997 (Act 572) which is in accordance with the need to accommodate growth.

The local authority in Malacca currently uses both the National Heritage Act 2005 (Act 645) and Malacca Enactment no.6 of 1988 (Controller 1 and 2). Apart from the Acts, the structure plan of the city is used as the main guide to ensure the retention of the old buildings in the old town. Presently, there are three major zones: core zone which covers the main heritage area, buffer zone and the area outside (Controller 1 ).

The series of actions taken to ensure the retention of the historic buildings include the requirement to get an approval from MBMB before any renovation is executed. This includes the replacement of any element on the façade. As an example, the grade and the size of the timber pieces has to be the same as the original. However, there is some flexibility depending on circumstances. Regarding theair well, the firstone cannotbe roofed. For the second and third air well, Fire Brigade Department has to be consulted if the owner decide to close them. The maximum height for a new building is up to 3 storeys only and the height of a new building for an empty site within the historic city of Malacca has to follow the lower adjacent building (Controller 3). For the buffer zone, new buildings are not allowed to be higher than 3 storeys (40 feet). Any renovation proposals to the existing built structures need to be submitted to MBMB for approval (Controller 1).

In the case of removing old buildings, the fine has been increased. Under the Malacca Enactment no.6 1988 the fine for removing an old building was only RM10,000.00. Under the National Heritage Act 2005 (Act 645), the fine has increased to RM500,000.00 (Controller 3; National Heritage Act 2005). This relates better to the current price of two storey houses but is still considerably cheap for heritage buildings. 


\subsection{Methodology}

The methodology includes site observation, building study, literature review interview of the residents and in-depth interview of the controllers. A standard questionnaire was given to the local residents and the interview was done on one to one basis. The collection of data was done with the help of architecture students in the Architecture Department, Universiti Teknologi Malaysia. Two hundred (200) local residents were interviewed. In-depth interview was also carried out involving 3 controllers but was done earlier (Wan Hashimah, 2009). The main concern was to find out the details on the enforcement of the policies relating to conservation of the historic buildings. This includes representatives from Malacca Museum Department (PERZIM), Malaysia Architectural Museum, Malacca and Historic Malacca City Council (MBMB). All the data were then analysed through triangulation and only then the results were drawn.

\subsection{Results and Discussions}

Only a few of the Dutch houses have survived unchanged due to layers of intervention by later occupants that erased most of their original features. In a research conducted by Raja Nafida (2008) it was found that only 112 buildings in the area retain the original façade and interior of the earlier Dutch houses. These can be easily recognised due to the lower height and simpler facade. The historical residential and commercial quarters are located as it stands today. The survey done in 2003 by Malacca City Council noted that the major land use in the historic city of Malacca was commercial $(35.76 \%)$ followed by residential or row houses $(20.63 \%)$. The history and the current use of the buildings within the area shows that they have gone through some phases of transformation due to the change of ownership and the changing patterns of life. It also indicates that the historic buildings have the ability to adapt to new needs.

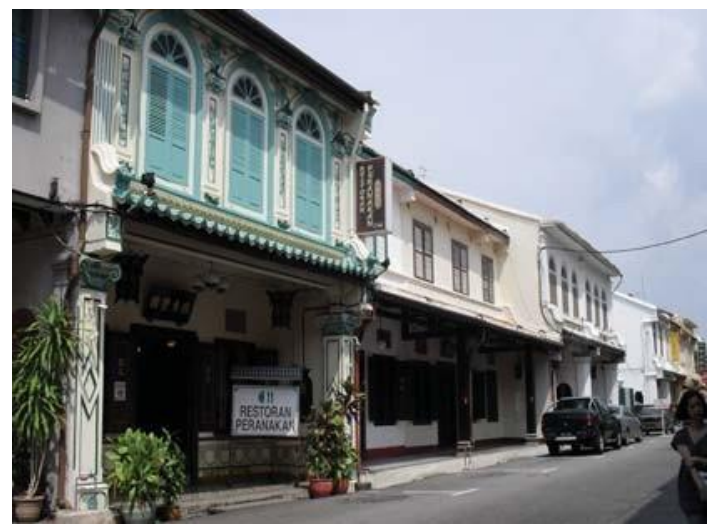

Figure 3: A view along Jalan Tun Tan Cheng Lock

(Source : Author, 2011) 
Through observation, the majority of the buildings within the area are still in use. Apart from the shop houses and the row houses there are also buildings with different uses. These buildings are basically the rehabilitation of the earlier shop houses or the row houses. This is evident along Jalan Tun Tan Cheng Lock where more than 5 hotels were found (Figure 3). Baba House Hotel, for instance was built from the rehabilitation of four row houses. Modern facilities were added to suit the new requirements. This includes toilets and fire requirements. Puri Hotel is another example of a restored row house with all the modern amenities. The adherence to the fire requirement of the Hotel is rather obvious since the external fire exit can be seen on one side of the building.

The local residents involved in the interview consisted of $86.9 \%$ Chinese, $5.68 \%$ Malay, $4.5 \%$ Indians and $2.8 \%$ others. This reflects the actual population of the area that is dominated by the Chinese. The majority of them were from the age group of 26 to 50 years old. The findings suggest that the majority (61.0\%) of the local residents were notaware of the policies enforced by the local authority on historic buildings in the area (Table 1). The local residents who were aware of the policy related to the retention of the height and the façade of the buildings. Some also mentioned that the colour for the façade is controlled by the authority. However, none of them mentioned about the specific requirements relating to the interior. The majority of the local residents considered that they can change the interior design but not the actual fabric of the buildings. The restriction concerning the first block and the courtyards as quoted by the controllers in Section 2.2 was not mentioned by any of them.

The majority of the local residents agreed that the local government need to enforce policies on the historic buildings to restrict them from making any unnecessary changes and to ensure the retention of the buildings. According to them the buildings are mostvaluable due to their historic value and as assets to tourism.

Table 1: Awareness of local residents on the policies

\begin{tabular}{|l|l|l|}
\hline AWARENESS OF POLICIES & NUMBER & PERCENTAGE \\
\hline Yes & 78 & $39.0 \%$ \\
\hline No & 122 & $61.0 \%$ \\
\hline TOTAL & 200 & $100 \%$ \\
\hline
\end{tabular}

(Source : Author, 2011)

Table 2: Reasons for comfort in working in the interior

\begin{tabular}{|l|c|c|}
\hline REASONSFOR COMFORTINWORKING (INTERIOR) & NUMBER & PERCENTAGE \\
\hline Structural - long space & 91 & $50.0 \%$ \\
\hline Functional - ventilation, lighting & 45 & $25.0 \%$ \\
\hline Preservation & 20 & $11.0 \%$ \\
\hline Attachment to the place & 20 & $11.0 \%$ \\
\hline Economy & 6 & $3.0 \%$ \\
\hline Total & $182(91.0 \%)$ & $100.0 \%$ \\
\hline
\end{tabular}

(Source : Author, 2011) 
The usability of the historic buildings in the area is in line with the finding of the interview whereby the majority $(182,91.0 \%)$ of the local residents perceived the area to be comfortable places for working mainly due to the long interior (Table 2). The finding is similar to the earlier survey done in 2006 (Wan Hashimah, 2009). It was also found that the majority of the local residents preferred to stay elsewhere and go to the area only to work. The reasons include discomfort and the unsuitability of the area for raising children.

\subsection{Conclusion}

It can be concluded that there is a lack of awareness among the local residents on some policies imposed by the local government regarding the historic buildings. Therefore, an effort need to be done such as workshops, fliers etc. to ensure that the knowledge reach them. This is important since the historic buildings within the area are largely owned by the local residents and they can damage the buildings without knowing the consequences.

On the whole, the findings of the research suggest that the buildings within the area were well sustained and the buildings have the ability to adapt to new uses. The residents had both positive and negative perceptions on the use of old building structures as living spaces. The majority of them find the historic buildings as suitable places for working but not for staying. Some strategies are thus needed to ensure the continuous use and sustainability of the buildings while at the same time able to satisfy the current demands of the modern society.

\section{Acknowledgement}

This study was made possible by the continuous support from Universiti Teknologi Malaysia.

\section{References}

Cantacuzino,S. andBrandt, S.(1980). Saving OldBuildings. London:Architectural Press.

Feilden, B. M. (1982). Conservation of Historic Buildings. London: Butterworth Scientific.

Historic Melaka City Council (MBMB) (2003). The Study on the Improvement and Conservation of Historical Urban Environment in the Historical City of Melaka. Melaka.

Jokilehto, J. (2002). A History of Architectural Conservation. (3rd. ed.). Oxford: Butterworth Heinemann.

Lam, Kok Liang (2002). Public Participations. Malacca City Council Seminar: The Study on Improvement and Conservation of Historical City of Melaka. Melaka.

Laurens, V. (1998). The Colonial Legacy in Melaka. In Chen, Voon Fee (Ed.). Architecture: The Encylopaedia of Malaysia. (pp. 62-63). Kuala Lumpur:Editions Didier Millet.

Lim, Huck Chin and Fernando, J. (2006). Malacca: Voices from the Street. Malaysia: Lim Huck Chin.

Nordin Hussin (2002). Social Life in Two Colonial Port-towns: Dutch-Melaka and English-Penang 1780-1830. The 
Penang Story-International Conference. Penang.

Nor Zalina Harun (2007). Problems involved in the Conservation of Historic Settlements in Malaysia: Case Study of Kuala Selangor. Jurnal AlamBina. Jilid 9 (3) (2007). 83-89.

Raja Nafida Raja Shahminan (2008). Kajian Tipologi Rumah Kedai Awal Era Belanda di Bandar Melaka: Sumbangan Kepada Bidang Pemuliharaan di Malaysia. : PhD thesis, Universiti Teknologi Malaysia.

Wan Hashimah Wan Ismail (2009). Users' Perceptions on the Heritage Value of the Old Shophouses in the Historic City of Malacca. Johor: PhD thesis, Universiti Teknologi Malaysia.

Zalina Samadi (2009). Integrating Architectural Heritage: An Approach for Urban Revitalization.Selangor:University PublicationCentre(UPENA),Universiti Teknologi MARA. 